\title{
Bruselloz Tanılı 94 Çocuk Hastanın Retrospektif Olarak Değerlendirilmesi
}

\author{
RETROSPECTIVE EVALUATION OF 94 PEDIATRIC PATIENTS WITH BRUCELLOSIS DIAGNOSIS
}

\author{
${ }^{1}$ Soner Sertan KARA, ${ }^{2}$ Mehtap Hülya ASLAN, ${ }^{3}$ Burcu VOLKAN, ${ }^{3}$ Metin ÖZEL, ${ }^{3}$ Ali FETTAH \\ ${ }^{1}$ Erzurum Bölge Eğitim ve Araştırma Hastanesi, Çocuk Enfeksiyon Hastalıkları Kliniği, Erzurum \\ ${ }^{2}$ Erzurum Bölge Eğitim ve Araştırma Hastanesi, Mikrobiyoloji Bölümü, Erzurum \\ ${ }^{3}$ Erzurum Bölge Eğitim ve Araştırma Hastanesi, Çocuk Sağlığı ve Hastalıkları Kliniği, Erzurum
}

\begin{abstract}
öz
Amaç: Bu çalışmada hastanemizde bruselloz tanısı konulan çocuk hastaların sosyodemografik, klinik ve laboratuvar özelliklerinin değerlendirilmesi amaçlanmıştır.
\end{abstract}

Gereç ve Yöntem: Çalışmada Eylül 2009-Aralık 2014 tarihleri arasında, üçüncü basamak sağlık merkezi olan hastanemizde bruselloz tanısı konulan 16 yaş altındaki hastalar retrospektif olarak incelenmiştir.

Bulgular: Çalışma süresi boyunca dosya verileri yeterli bulunan 94 çocuk çalışmaya dahil edilmiştir. Hastaların yaş ortalaması $8.85 \pm 3.69$ yıldır ve \%46.8'si erkek, kalan \%53.2'si kızdır. Hastaların \%75.5'i kırsal kesimde yaşamakta, \%87.2'inin pastörize edilmemiş süt-peynir tüketimi, \%69.1'inin ailesinde hayvancılıkla uğraşma, \%30.8'inin ailesinde bruselloz geçirme öyküsü bulunmaktadır. Hastaların doktora ilk başvurusu, semptomları başladıktan ortanca 16 (aralık, 7-45) gün sonra olmuştur. Hastaların en sık başvuru yakınmaları; ateş (\%88.2), artralji (\%85.1) ve halsizlik (\%80.8) iken; en sık fizik inceleme bulguları ateş yüksekliği (\%44.6), artrit (\%12.7) ve hepatomegali (\%8.5) olmuştur. Tanı konulan artritler monoartiküler özellikte ve en sık diz eklemi tutulumu mevcut idi. Başvuruda hastaların lökosit, C-reaktif protein, eritrosit sedimantasyon hızı ve transaminaz düzeyleri normal sınırlardaydı. Hastaların \%13.5'inde en az bir seride sitopeni saptandı. Rose Bengal testi hastaların \%91.5'inde, Brusella standart tüp aglütinasyon testi \%88.2'sinde, Brusella Coombs aglütinasyon testiyse \%94.6'sında pozitifti. Hastaların \%7.1'inde kan kültüründe Brucella spp. üremesi oldu. İki hastada hepatit ve 1 hastada meningoensefalit saptandı. Yedi hastada bir yıl içerisinde relaps veya reenfeksiyon gelişirken çalışmada mortalite gözlenmedi.

Sonuç: Brusellozis ülkemizde Doğu Anadolu Bölgesi'nde sık görülmektedir. Özgül olmayan klinik ve laboratuvar bulguları nedeniyle özellikle endemik bölgelerde sürekli akılda bulundurulması gereken bir hastalıktır. Antibiyotik tedavisini uygun sürede verilmesiyle komplikasyonlar ve tedavi başarısızlığı riski azalacaktır.

Anahtar kelimeler: Bruselloz, Çocuk, Doğu Anadolu Bölgesi,

Geliș Tarihi / Received: 14.12.2015

Kabul Tarihi / Accepted: 28.01.2016

Yazışma Adresi / Correspondence: Uzm. Dr. Soner Sertan KARA

Erzurum Bölge Eğitim Araştırma Hastanesi, Çocuk Enfeksiyon Hastalıkları Kliniği, Palandöken, Erzurum

drsoner@yahoo.com

\section{ABSTRACT}

Objective: In this study, evaluation of socioeconomic, clinical, and laboratory properties of children with brucellosis in our hospital was aimed.

Material and methods: Between September 2009-December 2014, children below 16 years old, who were diagnosed with brucellosis in Tertiary Medical Center, were retrospectively evaluated.

Results: During the study period, 94 children with adequate data were included. The mean age of patients was $8.85 \pm 3.69$ years and $46.8 \%$ was male. Of all, $75.5 \%$ were living in rural area, $87.2 \%$ had consumption of unpasteurized milk-cheese, $69.1 \%$ had animal husbandry, and $30.8 \%$ had family brucellosis history. Median admission time after the symptoms was 16 (range, 7-45) days. The most frequent admission symptoms were fever $(88.2 \%)$, arthralgia (85.1\%), and malaise $(80.8 \%)$, while physical examination findings were fever (44.6\%), arthritis $(12.7 \%)$, and hepatomegaly (8.5\%). All of the cases of arthritis were monoarticular and mostly knee was involved. Leukocyte count, C-reactive protein, erythrocyte sedimentation rate, and transaminases were within normal limits. At least one type of cytopenia was observed in $13.5 \%$ of patients. Rose Bengal test was positive in $91.5 \%$, Brucellar standard tube agglutination test was positive in $88.2 \%$, Brucellar Coombs agglutination test was positive in $94.6 \%$ and Brucella spp. grew in blood culture $\% 7.1$ of patients. Two patients had hepatitis and 1 patient had meningoencephalitis. In one year, 7 patients had relapse/ reinfection. No mortality was observed in the study.

Conclusion: Brucellosis is a frequent disease in Eastern Anatolian Region and it should always be kept in mind in especially endemic countries due to nonspecific clinical and laboratory findings. By the help of appropriate antibiotic treatment duration, complications of the disease and treatment failure could be diminished.

Key words: Brucellosis, Child, Eastern Anatolian Region, 


\section{GíRiş}

Bruselloz, hayvanlarda Brusella türü bakteri tarafından oluşturulan zoonotik bir hastalıktır. Brusellozun gerçek insidansı, istenen düzeyde bildirim yapılmaması, bazı olguların subklinik olarak seyretmesi nedeniyle bilinmemektedir (1). Ülkemizde ilk laboratuvar tanılı bruselloz olgusu 1915 yılında tanımlanmış olup, son dönemde hastalığın seroprevalansı \%3-14 arasında bildirilmiştir $(2,3)$. Ancak tahmin edilen, bunun çok daha üstünde olabileceğidir. Doğu Anadolu bölgesi, hastalığın Güneydoğu Anadolu ve İç Anadolu ile birlikte en sık görüldüğü bölgelerden biridir (4). Rastlantısal bir konak olan insanlara hastalığın bulaşı, pastörize edilmemiş süt ve süt ürünlerinin tüketilmesi, enfekte hayvanlarla veya onların sekresyonlarıyla temas ya da inhalasyonu yoluyla, bazen de laboratuvar çalışanlarının mesleki kazaları sırasında olmaktadır (5). İnsanları enfekte eden brusella türleri B. abortus, B. melitensis, B. suis ve B. canis olsa da, en sık karşılaşılan tür B. melitensis'tir (6).

Brusella enfeksiyonlarının bulguları patognomonik olmayıp, subklinik enfeksiyondan, ağır bakteriyemi veya santral sinir sistemi enfeksiyonlarına kadar değişken kliniklerle karşımıza çıkabilmektedir. Hastalık endemik bölgelerde pek çok başka hastalığın ayırıcı tanısı içinde yer almaktadır. Etken, hematojen yolla yayılıp çoğu zaman retiküloendotelyal sistemi tutar ve eklemler, santral sinir sistemi, kalp ve böbrekler gibi pek çok organ ve sistemin tutulumu görülebilir (7). Uygun şekilde tedavi edilmeyen olgularda ağır sekeller ve uzun dönemde artmış morbidite görülebilmektedir.

Bu çalışmada kliniğimizde bruselloz tanısı almış çocuk hastaların klinik ve epidemiyolojik özelliklerinin, ülkemizde yapılmış diğer çocukluk çağı brusellozunu kapsayan çalışmalarla birlikte irdelenmesi amaçlanmıştır.

\section{GEREÇ VE YÖNTEM}

Çalışmada Eylül 2009-Aralık 2014 tarihleri arasında Erzurum Bölge Eğitim ve Araştırma Hastanesi'nde Çocuk Sağlığı ve Hastalıkları ve Çocuk Enfeksiyon polikliniklerinde bruselloz tanısı konulan hastalar retrospektif olarak incelendi. Hastaların sosyodemografik özellikleri, baş- vuru yakınmaları, klinik bulguları ve laboratuvar özellikleri değerlendirildi. Çalışmanın etik olarak uygunluğu yerel etik kurul tarafından onaylandı. Çalışmaya Erzurum Bölge Eğitim Araştırma Hastanesi Klinik Mikrobiyoloji Laboratuvarı'nda Brusella standart tüp aglütinasyon (Wright) veya Brusella Coombs aglütinasyon testleri $\geq 1: 160$ titrede saptanan veya kan kültüründe Brusella spp. üreyen 16 yaş ve altındaki çocuklar dahil edildi.

Hastaların yaşı, cinsiyeti, geliş yeri (köy-kasaba-kent merkezi), pastörize olmamış süt-süt ürünleri tüketip tüketmediği, şikayetlerinin başlama süresi, ailesinde bruselloz öyküsü olup olmadığı, ailenin hayvancılıkla uğraşıp uğraşmadığı, başvuru yakınmaları, sistem sorgulaması, fizik muayene bulguları, başvuru anındaki laboratuvar ve mikrobiyolojik incelemeleri (tam kan sayımı, rutin biyokimyasal testler, C-reaktif protein [CRP], eritrosit sedimantasyon hızı [ESH], Rose Bengal testi, Brucella standart tüp aglütinasyon ve Coombs aglütinasyon testleri, kan kültürü), hastalara başlanan tedavi rejimleri, ilaç yan-etkileri ve komplikasyonlar kaydedildi.

İstatistiksel analizler SPSS (Statistical package for the Social Sciences) versiyon 18.0 yazılımı kullanılarak yapıldı. Değişkenlerin normal dağılıma uygunluğu Kolmogrov-Smirnov/Shapiro-Wilk testleri ile incelendi. Tanımlayıc analizler normal dağılan değişkenler için ortalama \pm standart sapma, normal dağılmayanlar değişkenler için ortanca (minimum-maksimum) olarak verildi. Kategorik değişkenler ise "\%" olarak ifade edildi.

\section{BULGULAR}

Çalışma süresi boyunca bildirimi yapılan 213 çocuk hastandan verileri yeterli bulunan 94'ü çalışmaya dahil edilmiştir. Çalışmaya dahil edilen hastaların yaş ortalaması $8.85 \pm 3.69$ yaştır ve bu hastaların 44'ü (\%46.8) erkektir. Hastaların 71'i (\%75.5) kırsal kesimde, 23'ü (\%24.5) kent merkezlerinde yaşamaktadır. Hastaların 82'sinde (\%87.2) pastörize edilmemiş süt-peynir tüketimi, $65^{\prime}$ inin ailesinde (\%69.1) hayvancilıkla uğraşma, 29'unun (\%30.8) ailesinde bruselloz geçirme öyküsü bulunmaktaydı. Doktora ilk başvuru, semptomlar başladıktan ortanca 16 [7-45] gün sonra olmuştu (Tablo 1). 
Illk başvuruda hastaların en sık yakınmaları; ateş $(n=83, \% 88.2)$, artralji $(n=80, \% 85.1)$ ve halsizlik $(n=76, \% 80.8)$ idi. Fizik incelemelerinde, 42 (\%44.6) hastada ateş yüksekliği, 12'sinde (\%12.7) artrit, 8'inde (\%8.5) hepatomegali, 6'sında (\%6.3) splenomegali, 2'sinde(\%2.1) ise lenfadenopati vardı (Tablo 1). Artrit, hastaların tümünde monoartikülerdi. En sık tutulan eklem

Tablo 1: Çalışmadaki Hastaların Sosyodemografik ve Klinik Özellikleri

\begin{tabular}{|c|c|}
\hline & Hasta sayısı (yüzde) \\
\hline \multicolumn{2}{|l|}{ Sosyodemografik özellikler } \\
\hline Yaş (yil) (ortalama \pm SD) & $8.85 \pm 3.69$ yaş \\
\hline Erkek cinsiyet & $44(\% 46.8)$ \\
\hline Kırsal alanda yaşama & $71(\% 75.5)$ \\
\hline Pastörize olmayan süt-süt ürünü tüketimi & $82(\% 87.2)$ \\
\hline Ailenin hayvancılıkla uğraşması & $65(\% 69.1)$ \\
\hline Ailede brusellozu olan başka bir birey varlığı & $29(\% 30.8)$ \\
\hline Başvurudan önceki semptom süresi [ortanca (min-maks)] & $16(7-45)$ \\
\hline \multicolumn{2}{|l|}{ Başvurudaki yakinmalar } \\
\hline Ates & $83(\% 88.2)$ \\
\hline Artralji & $80(\% 85.1)$ \\
\hline Halsizlik & $76(\% 80.8)$ \\
\hline Terleme & $55(\% 58.5)$ \\
\hline Kilo kaybı & $30(\% 31.9)$ \\
\hline Karın ağrısı & $22(\% 23.4)$ \\
\hline Baș ağrisı & $13(\% 13.8)$ \\
\hline \multicolumn{2}{|l|}{ Başvurudaki fizik muayene özellikleri } \\
\hline Ateş yüksekliği & $42(\% 44.6)$ \\
\hline Artrit & $12(\% 12.7)$ \\
\hline Hepatomegali & $8(\% 8.5)$ \\
\hline Splenomegali & $6(\% 6.3)$ \\
\hline Lenfadenopati & $2(\% 2.1)$ \\
\hline Döküntü & $2(\% 2.1)$ \\
\hline \multicolumn{2}{|l|}{ Prognoz } \\
\hline Relaps/reenfeksiyon* & $7(\% 7.4)$ \\
\hline Mortalite & $0(\% 0)$ \\
\hline
\end{tabular}

ise dizdi $(n=7)$. Üç hastada sakroiliak, 2 hastada kalça eklemi tutulumu mevcuttu. Tanı anında hastaların laboratuvar incelemesinde, kan lökosit değeri ortalama 8.549 $\pm 3.126 \times 109 / L, C R P$ düzeyleri ortanca 2.1 (aralık: 1-139) mg/dL, ESH ortanca 12 (aralık: 2-80) mm/saatti (Tablo 2). Hastaların 13'ünde (\%13.5) sitopeni saptandı. Bu hastaların 7'sinde sadece lökopeni, 3'ünde anemi, 1'inde anemi ve lökopeni, 2'sindeyse

Tablo 2: Bruselloz Tanısıyla İzlenen Hastaların Tanı Anındaki Laboratuvar Özellikleri

\begin{tabular}{|c|c|}
\hline Beyaz küre sayısı (/uL) (ortalama \pm SD) & $8.549 \pm 3.126$ \\
\hline Hemoglobin değeri $(\mathrm{gr} / \mathrm{dL})($ ortalama $\pm \mathrm{SD})$ & $13.3 \pm 3.5$ \\
\hline Platelet sayisi (/uL) (ortalama \pm SD) & $324,380 \pm 96,064$ \\
\hline${ }^{\mathrm{a} C}$ C-reaktif protein değeri [ortanca (min-maks)] & $2.1(1-139)$ \\
\hline 'Eritrosit sedimentasyon değeri [ortanca (min-maks)] & $12(2-80)$ \\
\hline 'Serum AST düzeyi [ortanca (min-maks)] & $36(12-2512)$ \\
\hline 'Serum ALT düzeyi [ortanca (min-maks)] & $25(2-1629)$ \\
\hline 'Serum GGT düzeyi [ortanca (min-maks)] & $15(2-62)$ \\
\hline Rose Bengal testi pozitifliği n (\%) & $86(\% 91.5)$ \\
\hline \multicolumn{2}{|l|}{ Brusella standart tüp aglütinasyon testi n (\%) } \\
\hline$<160$ & $11(\% 11.7)$ \\
\hline $1 / 160$ & $29(\% 30.8)$ \\
\hline $1 / 320$ & $48(\% 51.0)$ \\
\hline $1 / 640$ & $2(\% 2.1)$ \\
\hline $1 / 1280$ & $4(\% 4.2)$ \\
\hline \multicolumn{2}{|l|}{ Brusella Coombs aglütinasyon testi n (\%) } \\
\hline$<160$ & $5(\% 5.3)$ \\
\hline $1 / 160$ & $32(\% 34.0)$ \\
\hline $1 / 320$ & $40(\% 42.5)$ \\
\hline $1 / 640$ & $7(\% 7.4)$ \\
\hline $1 / 1280$ & $10(\% 10.6)$ \\
\hline Kan külttürü pozitifliği n (\%) $(5 / 70)^{*}$ & $5(\% 7.1)$ \\
\hline
\end{tabular}

pansitopeni mevcuttu. Başvuru esnasında AST düzeyi ortanca 36 (aralık: 12-2512) U/L, ALT dü- zeyi ortanca 25 (2-1629) U/L olarak saptanırken hastaların 2'sinde Brusellar hepatit mevcuttu. Bir (\%1.1) hastada ise nörobruselloz (meningoensefalit) saptandı.

Hastaların \%91.5'inde Rose Bengal testi pozitifti. Brusella standart tüp aglütinasyon testi hastaların 83'ünde (\%88.2), Brusella Coombs aglütinasyon testi ise hastaların 89 'unda (\%94.6) $\geq 1: 160$ titrede saptandı. Kan kültürü gönderilen 70 olgunun 5'inde (\%7.1) Brucella spp. izole edildi. Brusellar meningoensefalit tanılı hastanın beyin omurilik sıvısında (BOS) brusella aglütinasyon testleri pozitifti ve BOS kültüründe Brucella spp. üremesi oldu. Kültür üremesi olan hiçbir hastaya teknik yetersizliklerden dolayı alt tip tayini yapılamadı. Sepsis kliniği olan veya farklı organ tulumu olan (göz, genitoüriner, pulmoner, kardiyovasküler sistemler, vs.) hastaya rastlanmadı.

Tanı alan hastalardan sadece $5^{\prime} \mathbf{i}(\% 5.3)$ hepatit, meningoensefalit ve sakroileit gibi komplikasyonlar nedeniyle hastaneye yatırıldı. Tedavide 8 yaş üzerindeki hastalara doksisiklin $(4 \mathrm{mg} / \mathrm{kg} /$ gün), rifampisin (20 mg/kg/gün) ya da streptomisin ( $20 \mathrm{mg} / \mathrm{kg} / \mathrm{gün}) ; 8$ yaş altındaki hastalara trimetoprim-sulfametoksazol (trimetoprim dozuna göre $10 \mathrm{mg} / \mathrm{kg} / \mathrm{gün}$ ), rifampisin (20 mg/ $\mathrm{kg} / \mathrm{gün}$ ) ya da gentamisin ( $5 \mathrm{mg} / \mathrm{kg} / \mathrm{gün}$ ) kombinasyonları verildi. Nörobrusellozu olan olguya ise seftriakson (100 mg/kg/gün), rifampisin (20 mg/kg/gün) ve gentamisin ( $5 \mathrm{mg} / \mathrm{kg} / \mathrm{gün}$ ) tedavisi kombine olarak verildi. Antibiyotik tedavisi6 hafta süreyle verilirken, sakroileit olgularında 4 ay, meningoensefalit olgusunda 6 ay süreyle verildi. Tedavilere bağlı minör gastrointestinal sistem yakınmaları (bulantı, karın ağrısı) dışında ciddi bir yan-etki gözlenmedi. Tedavi bitiminden sonraki 1 yıl içerisinde 7 hastada relaps veya reenfeksiyon saptandı. Bu olgular 6 haftalık tedavi verilen, ancak tedaviye uyumsuz olduğu düşünülen hastalardı. Aynı kombinasyonlar hastalara tekrar verildi. Çalışmada bruselloza bağlı mortalite gözlenmedi.

\section{TARTIŞMA}

Bruselloz en sık karşılaşılan zoonotik hastalıklardan birisidir. Pek çok gelişmiş ülkede hastalığın sıkı kontrolü sağlanmış olsa da, ülkemizin de yer aldığı Akdeniz Bölgesi, Ortadoğu ve Batı Asya 
ülkelerinde hala önemli bir hastalık olarak yerini korumaktadır (8). Brusellozun bilinen en sık bulaş yolu pastörize edilmemiş süt-peynir gibi hayvansal besinlerin tüketimidir. Bu çalışmada da hastaların büyük bir kısmının kırsal kesimde yaşadığı ve pastörize edilmemiş süt-peynir tükettiği görülmüştür. Hastalığın diğer bir bulaş yolu ise hasta/kontamine hayvanlarla ya da hayvan sekresyonları ile temas olmasıdır (6). Çalışma popülasyonunun \%69.1'inin ailesinin hayvancılıkla uğraştığı öğrenilse de, çalışmamızda hastaların hayvanlarla direkt temasıyla ilgili olarak net bir veriye ulaşılamamıştır. Bununla beraber, epidemiyolojik açıdan, hasta popülasyonun daha çok kırsal kesimden gelmiş olması, taze peynir tüketiminin daha sık oluşuyla ilişkilendirilebileceği gibi, kırsal kesimdeki olası daha düşük sosyokültürel düzey, hastalıktan korunmak için alınacak önlemlerin yetersiz kalmasına neden olmuş olabilir. Bireyin ailesinde bruselloz öyküsü olması da hastalığın ortaya çıkması için bir risk faktörü olarak kabul edilebilir (9). Bu çalışmada da hastaların yaklaşık üçte birinde ailesinde bruselloz geçiren birey bulunmaktaydı. Brusellozun bulaşı intrauterin ve perinatal dönemden itibaren olabilmektedir $(10,11)$. Ancak ülkemizin değişik bölgelerinde yapılan çalışmalarda bruselloz tanısı alan çocuk hastaların yaş ortalaması daha çok ergenlik çağı başlarıdır $(7,12-14)$. Bu çalışmada da hastaların yaş ortalaması diğer çalışmalar ile benzer olarak bulunmuştur.

Bruselloz pek çok nonspesifik semptoma yol açan, multisistemik tutulumla seyreden bir hastalıktır. Semptomların ortaya çıkma süresi, bakteri vücuda alındıktan sonra 14-28 gündür (6). Semptomların ortalama görülme süresi, Yoldaş ve arkadaşlarının çalışmasında $31.85 \pm 44.3$ gün (9), Çelebi ve arkadaşlarının çalışmasında ise 4 hafta olarak bildirilmiştir (12). Bu çalışmada ise doktora ilk başvuru, semptomlar başladıktan ortanca 16 [aralık, 7-45] gün sonra olmuştur. Bu durumun, çalışma popülasyonun üçte birinin aile bireylerinde bruselloz olmasının farkındaı̆ğı arttırmasına bağlı olabileceği düşünülmüştür. Brusellozda çocukluk çağında bildirilen en sık yakınmalar ateş, artralji, halsizlik, iştahsızılı ve karın ağrısı gibi pek çok hastalıkla karışabilecek olan semptomlardır (14-16). Bu çalışmada da hastaların ilk başvuruda en sık bildirdiği yakınmalar; ateş, artralji ve halsizlik olmuştur.
Çalışmamızda hastaların fizik incelemelerinde en sık ateş yüksekliği mevcuttu. Osteoartiküler tutulum çocukluk çağı brusellozunda sık görülen bir tutulumdur ve en sık büyük, ağırlık taşıyan eklemler etkilenmektedir. Parlak ve arkadaşlarının 496 vakalı çocuk bruselloz serisinde artrit oranı \%10.1 olarak bildirilmiştir (14). Bizim çalışmamızda da hastaların \%12.7'sinde artrit saptandı ve tümü monoartritti. En sık tutulan eklem dizdi. Bosilkovski ve arkadaşlarının çalışmasında ise kemik eklem tutulumu olan brusellozlu çocuk hastaların \%71.4'ünde monoartiküler tutulum saptanmıştır. Bu hastaların yaklaşık yarısında kalça tutulumu görülürken, \%30.1'inde bizim çalışmamızda olduğu gibi diz tutulumu bildirilmiştir (17). Bruselloza bağlı olarak hepatomegali, splenomegali ve lenfadenopati de görülebilen diğer muayene bulgularıdır (18). Bizim çalışmamızda da 8 hastada hepatomegali, 6 hastada splenomegali, 2 hastada ise lenfadenopati görülmüştür.

Hastalığın kesin tanısı kanda ya da dokularda kültür veya Polimeraz Zincir Reaksiyonu gibi moleküler yöntemlerle bakterinin gösterilmesidir. Ancak klinikte en sık kullanılan tanı yöntemi çapraz reaksiyon riski taşısa da serolojik testlerdir (18). Tarama testi de denilebilecek Rose Bengal testi çalışmamızda, hastaların \%91.5'inde pozitifti. Brusella standart tüp aglütinasyon testi hastaların \%88.2'sinde, Brusella Coombs aglütinasyon testiyse $\% 94.6$ 'sında pozitifti. Kan kültürü pozitifliği ülkemizde yapılan çocukluk çağı brusellozu çalışmalarında \%17.8 - 27.4 arasında bildirilmiştir $(7,12)$. Bizim çalışmamızda ise kan kültürü ile sadece 5 olguda Brucella spp. izole edildi ve diğer çalışmalara göre tespit oranı daha düşüktü. Brusellozun klinik bulguları oldukça değişken seyretmekte ve hastalık şiddeti bakterinin türüne bağlı olarak da değişmektedir. B. melitensis ile diğer türlere nazaran daha ağır semptomlar ve klinik tablolar ortaya çıkmaktadır (19). Çalışmamızda kültürde saptanan bakteriler için alt tip tayini yapılmamış ve kültür oranlarındaki düşüklüğün kan kültürü alım teknikleriyle (az miktarda kan alınması gibi) ilgili olabileceği düşünülmüştür.

C-reaktif protein, ESH gibi enfeksiyon belirteçleri ve karaciğer enzimleri hastalığın tanısında kullanılabilen ancak spesifik olmayan testlerdir. Benzer şekilde, CRP ve ESH gibi lökosit sayısı 
da çoğu vakada normal ya da hafif artmış düzeydedir $(20,21)$. Bu çalışmada da tanı anında hastaların lökosit, CRP ve ESH ortalama/ortanca düzeyleri normal aralıklardaydı. Hastalığın seyri esnasında karaciğerin tutulumu değişkenlik gösterebilir. Karaciğer enzimleri normal ya da hafif artmış olabileceği gibi, hepatosplenomegali, kronik süpüratif hastalık veya nadiren hepatit gelişmiş olabilir (22). Parlak ve arkadaşlarının (14) yaptığı çalışmada çocuk hastaların \%40'ında AST, \%30'unda ALT yüksekliği bildirilmiştir. Bizim çalışmamızda ise hastaların başvuru esnasında AST ve ALT ortanca değerleri normal sınırlarda saptanmış olup, transaminaz yüksekliği olan 2 hastaya hepatit tanısı konulmuştur. Brusellozlu olgularda laboratuvar bulgularına anemi, lökopeni, trombositopeni veya pansitopeni gibi hematolojik bulgular da eşlik edebilmektedir $(23,24)$. Bizim çalışmamızda da hastaların \%7.4'ünde lökopeni, \% 3.1'inde anemi, \%1'inde anemi ve lökopeni, \% 2.1'inde pansitopeni saptanmıştır.

Brusellozun en önemli komplikasyonlarından birisi de nörobrusellozdur. Kronikleşmeye eğilimli olan nörobruselloz genellikle menenjit ve meningoensefalit şeklinde prezante olur (25). Çocuklarda prevelansı \%0.8-1 olarak bildirilmiştir (26). Bu çalışmada da 1 (\%1.1) olguda Brusellar meningoensefalit tanısı konulmuştur. Hastalığın diğer komplikasyonları izlenmemiştir. Hastalığın tedavisinde başarı sağlayabilmek için her hastalıkta olduğu gibi, uygun sürede uygun antibiyotiklerin verilmesi gerekmektedir. Bu çalışmada da hastaların tümü doksisiklin, rifampisin ve trimetoprim sulfametaksazolün kombinasyonlarıyla tedavi edilmiş, hastaların 7'sinde tedavi sonrasında relaps/reenfeksiyon gelişmiştir. Tedavi başarısızlığı, daha çok relaps gelişmesine, tedaviye uyumsuzluğa ve ilaç yan-etkilerine bağlı görülmektedir (27). Hastaların endemik bölgede bulunması nedeniyle reenfeksiyon kesin olarak dışlanamasa da, aile ve hastaların tedaviye uyumsuzluğu göz önüne alındığında bu olguların daha çok relaps olduğu düşünülmüştür.

Sonuç olarak, Bruselloz ülkemizde yaygın olarak görülen bir hastalıktır. Doğu Anadolu Bölgesi de, hastalığın sık görüldüğü bölgelerimizden biridir. Özgül olmayan klinik ve laboratuvar bul- guları olsa da, yüksek komplikasyon riski taşıması, çocuk yaştaki insanları da etkileyebilmesi ve şüphe duyulduğunda tanı konulup kolaylıkla tedavi edilebilme şansı nedeniyle, ayırıcı tanıda akılda bulundurulması gereken bir hastalıktır.

\section{KAYNAKLAR}

1. Hatipoğlu ÇA, Kınıklı S, Tülek N ve ark. Bir eğitim hastanesinin İnfeksiyon Hastalıkları ve Klinik Mikrobiyoloji Kliniği'nde izlenen 202 bruselloz olgusunun epidemiyolojik verilerinin irdelenmesi. Klimik Dergisi 2005;18(3):94-8.

2. Doguer M, Yilmaz S. Brucellosis in Turkey (in Turkish). Etlik Vet Bakt Enst Derg 1963;2:1-20.

3. Turgut M , Turgut AT, Kosar U. Spinal brucellosis: Turkish experience based on 452 cases published during the last century. Acta Neurochir (Wien) 2006;148(10):1033-1044.

4. Buzgan $T$, Karahocagil $M K$, Irmak $H$ ve ark. Clinical manifestations and complications in 1028 cases of brucellosis: a retrospective evaluation and review of the literature. Int J Infect Dis 2010;14(6):e469-478.

5. Logan LK, Jacobs NM, McAuley JB, Weinstein RA, Anderson EJ. A multicenter retrospective study of childhood brucellosis in Chicago, Illinois from 1986 to 2008. Int J Infect Dis 2011;15(12):e812-817.

6. Long SS, Pickering LK, Prober CG (Editörler).Principles and Practice of Pediatric Infectious Diseases. In: Young EJ. Brucella Species (Brucellosis). 4. ed, Pennsylvania:Churchill Livingstone, 2012:876-80.

7. Tanir G, Tufekci SB, Tuygun N. Presentation, complications, and treatment outcome of brucellosis in Turkish children. Pediatr Int 2009;51(1):114-119.

8. Sabah AA, Aly AM, Tawab AH ve ark. Brucellosis in Egyptian female patients. J Egypt Soc Parasitol 2008;38(2):671-678.

9. Yoldas T, Tezer H, Ozkaya-Parlakay A, Sayli TR. Clinical and laboratory findings of 97 pediatric brucellosis patients in central Turkey. J Microbiol Immunol Infect 2015;48(4):446-449.

10. Aydın B, Beken S, Akansel R ve ark. Prematurity due to maternal brucella infection and review of the literature. Turk J Pediatr 2013;55(4):433-437.

11. Celebi G, Külah C, Kiliç S, Ustündağ G. Asymptomatic Brucella bacteraemia and isolation of Brucella melitensis biovar 3 from human breast milk. Scand J Infect Dis 2007;39(3):205-208.

12. Çelebi S, Hacımustafaoğlu M, Demirtaş F, Salı E, Gül Ü, Özel M. Çocukluk Çağında Bruselloz.J Pediatr Inf 2011;5:59-62.

13. Konca Ç, Tutanç $M$, Güneş $A$, Taş MA. Türkiye'nin Güneydoğusunda çocukluk çağı Brusellozu: Retrospektif analiz. İzmir Dr. Behçet Uz Çocuk Hast Dergisi 2013;3(1):54-59 
14. ParlakM, Akbayram S, Doğan $M$ ve ark. Clinical manifestations and laboratory findings of 496 children with brucellosis in Van, Turkey. Pediatr Int 2015;57(4):586-589.

15. Sasan MS, Nateghi M, Bonyadi B, Aelami MH. Clinical features and long term prognosis of childhood brucellosis in northeast Iran. Iran J Pediatr 2012;22(3):319-325.

16. Uluğ $M$, Yaman $Y$, Yapici $F$, Can-Uluğ N. Clinical and laboratory features, complications and treatment outcome of brucellosis in childhood and review of the literature. Turk J Pediatr 2011;53(4):413-424.

17. Bosilkovski M, Kirova-Urosevic V, Cekovska Z ve ark. Osteoarticular involvement in childhood brucellosis: experience with 133 cases in an endemic region. Pediatr Infect Dis J 2013;32(8):815-819.

18. Abuhandan M, Güzel B, Çakmak A, Çiçek A. Çocuklarda Bruselloz: 82 Olgunun Retrospektif Olarak Değerlendirilmesi. J Pediatr Inf 2012;6:74-78.

19. Hendricks MK, Perez EM, Burger PJ, Mouton PA. Brucellosis in childhood in the Western Cape. S Afr Med J 1995;85(3):176178.

20. Feiz J, Sabbaghian H, Miralai M. Brucellosis due to B. melitensis in children. Clinical and epidemiologic observations on 95 patients studied in central Iran. Clin Pediatr 1978;17(12):904e7.

21. Kurtaran B, Candevir A, Inal AS ve ark. Clinical appearance of brucellosis in adults: fourteen years of experience. Turk J Med Sci 2012;42(3):497e505.

22. Albayrak A, Albayrak F. Hepatic granulomas associated with brucellosis: hepatic granulomas and brucellosis. Hepat Mon 2011;11(1):1-2.

23. Akbayram $S$, Dogan $M$, Akgun $C$ ve ark. An analysis of children with brucellosis associated with pancytopenia. Pediatr Hematol Oncol 2011;28(3):203-208.

24. Citak EC, Citak FE, Tanyeri B, Arman D. Hematologic manifestations of brucellosis in children: 5 years experience of an Anatolian center. J Pediatr Hematol Oncol 2010;32(2):137140.

25. Haji-Abdolbagi $M$, Rasooli-Nejad $M$, Jafari $S$, Hasibi M, Soudbakhsh A. Clinical and laboratory findings in neurobrucellosis: Review of 31 cases. Arch Iranian Med 2008;11(1):21-25.

26. Martinez-Chamorro E, Munoz A, Esparza J, Munoz MJ, Giangaspro E. Focal cerebral imvolvement by neurobrucellosis: pathological and MRI findings. Eur J Radiol 2002;43(1):28-30.

27. Gür A, Geyik MF, Dikici B ve ark. Complications of brucellosis in different age groups: a study of 283 cases in southeastern Anatolia of Turkey. Yonsei Med J 2003;44(1):33-44. 